\title{
Continuing education programs for literacy teachers: concepts and practices ${ }^{1}$
}

\author{
Andrea Tereza Brito Ferreira a \\ Eliana Borges Correia de Albuquerque ${ }^{b}$ \\ Erica Windler ${ }^{\mathrm{c}}$
}

\section{Abstract}

The present article analyses the proposals of continuing training for literacy teachers in two counties of Recife Metropolitan Area, in order to understand the language conceptions and training that justify such practices. Our research illuminates huge differences between training practices in the two cities. In Camaragibe, the training program sought to incorporate teachers experiences, recognizing that language education is a comprehensive social practice. In Jaboatão, the training process focused on the use of educational materials developed by the program that included specific instructions for the teachers, reducing participants' role to that of completing predefined tasks rather than seeking their input in the process.

Keywords: Literacy. Continuing education programs. Educational politics.

\section{Introduction}

In recent decades, the Brazilian education system has undergone an unprecedented expansion. A rapid rise in student enrollments at all levels has instigated concerns over the quality of education being provided. Researchers are currently conducting numerous studies to shape the creation of public policies aimed at reversing the recent decline in student performance in schools throughout the nation. To address these problems, many specialists have proposed continuing teacher training programs as an effective means of attaining needed improvements (ANDRÉ, 2012; FUNDAÇÃO VICTOR CIVITA, 2011; GATTI, 2003).

\footnotetext{
a Universidade Federal de Pernambuco - UFPE. Recife, Pernambuco, Brasil.

b Universidade Federal de Pernambuco - UFPE. Recife, Pernambuco, Brasil.

Michigan State University. Michigan, EUA.

1 This essay is part of a larger research about continuing education financed by the CNPq (2011-2016).

Recebido em: 10 ago. 2016

Aceito em: 23 nov. 2016
} 
Research on the teaching profession and the training of educators demonstrates a shift in our understanding of educational practices and the teacher's role in today's society. Recent studies point to the importance of examining the ongoing process of teacher development and the influence of formal training, as well as the importance of professional and practical experiences, seeking to understand how these factors inform their work with students (IBERNON, 2010; NÓVOA, 1995; TARDIF, 1999).

In the last few years, in Brazil, the Ministry of Education (MEC), many universities and private institutions have formed partnerships with the goal of creating continued training programs for teachers in diverse areas of instruction that seek to integrate recent research developments in the field. In the area of language instruction, specifically literacy, state and local governments have encouraged extensive debates over how to guarantee that students learn to read and write during the early years of their elementary education.

Some continuing teacher training programs propose the use of "new approaches" to language instruction that promote "new conceptions" of training. Such programs are being developed in numerous states across Brazil, where they have adopted training models that bring together education students (future teachers) with teachers who are already working in the nation's public school system in early elementary classrooms (ANDRÉ, 2012).

In the current environment, it is important to review the roles that different groups play in the training process. Typically, the government is responsible for creating strategies and guidelines for educational improvements. Universities are responsible for initial teacher training, and for conducting research that examines how to effectively implement "new" theories, identifying potential changes that will benefit teaching and learning practices. The University is also involved in extension projects that promote continuing education for teachers.

Taken together, this partnership between governmental and academic actors promotes the creation of "new" training models that encourage increasing involvement in daily classroom activities and teaching practices. However, for better understanding this process we must thoroughly explore its components, avoiding simplistic cause and effect explanations. We must ask how the current proposals for teacher training in literacy are being introduced and how these proposals can effectively contribute to improving literacy practices. In order to understand the potential value of existing models for continuing teacher 
education in the field of literacy training, this essay will explore two distinct programs, analyzing what literacy teaching concepts are proposed and which are the continued education practices.

First, it deals with the theoretical framework about literacy teaching. It will also present some of the literacy teaching programs in Brazil. The second part is about the methodology and research results. Finally, we will make some comments about the analyzed Programs.

\section{Teacher training in Brazil: continuity and change}

The Brazilian government implemented the first guidelines and regulations for teaching practices during the Empire (1822-1889). These reforms brought about many transformations including the establishment of requirements for those seeking positions as teachers. For the first time, teachers had to undergo a selection process and demonstrate their legitimized knowledge, regulations that reflect the larger modernization process occurring in Brazil at the time. These transformations established the foundations of the teaching profession and ultimately influenced the construction of a professional identity for teachers. This process of professionalization intensified in the 1920s and 1930s, corresponding with intellectual movements that favored a free and secular education throughout the country (LÉLIS, 1989).

Beginning in the early 1970s, greater attention was given to didactic and methodological issues specifically related to teaching techniques. Specialists started exploring ways to enhance students' learning, emphasizing more focused teaching practices, technical planning, and evaluation methods, relegating the teacher's mastery of the content to a position of secondary importance. That being said, the teacher would first have to master the basic tools of his practice. This approach defined the teacher as simple "doer" of pre-elaborated tasks (providing step-by-step instructions and an extensive collection of progressive activities and lessons) and it was widely promoted through education manuals distributed to teachers throughout the country (GATTI, 2003; LÉLIS, 1989; MONTEIRO, 2001).

According to Monteiro (2001), this understanding of teachers' activities continues to influence everyday classroom practices, despite the concerns that specialists frequently expressed. By the 1980s, many voiced concern that the school system had become a tool for the reproduction of social inequalities and a vehicle for disseminating propaganda. They believed that schools were functioning as a governmental instrument that served state interests and 
supported the continuation of established class and social hierarchies. As such, the teaching profession came to emphasize policy questions and the more technical aspects of pedagogy. In this environment, teachers struggled to meet the real social needs of their students, especially those from the less fortunate sectors of the population. In order to achieve their goals and ensure effective professional performance, educators would come to rely on two things: mastery of the curriculum and a deep understanding of the complex factors that inform school policies and practices on different levels, giving particularly attention to the influence of social relations (LÉLIS, 1989).

At the time, a great deal of attention was given to the role of the teacher and the importance of their training. Based on the pedagogy of content, specialists increasingly support the idea that effective educational practices require more than the simple mastery of didactic tools that had long been the accepted foundation of the profession. Instead, teachers would need to utilize these tools in conjunction with practices of social transformation.

This understanding of teaching practice, which continues to influence many teachers, has now come under scrutiny because it fails to recognize teachers' subjectivity and their capacity for creativity in the classroom. Such critiques have presented teachers with new challenges as they seek to understand how to utilize the results of academic research in a meaningful way that recognizes the realities of the classroom and the school community (GATTI, 2003).

In recent decades, the content of the school curriculum has come into question, particularly with regard to the teacher-knowledge relationship defined by the traditional method of rationale-technique. Many have also begun to doubt the non-directive teaching method, a method that emphasizes student-knowledge without addressing the "universal" knowledge that comes naturally to the student. However, recent research increasingly recognizes the need to understand the specifics of educational experiences within the school environment.

"School knowledge" is now understood as a method that recognizes a level of expertise that operates with its own cognitive settings, separate from scientific knowledge. According to Monteiro (2001), this knowledge emerges from the needs and directives of the educational process, involving questions of didactic transposition, reference knowledge and daily life that includes a historical and socio-cultural dimension. In an attempt to develop social/professional practices that correspond with the realities of both educational requirements and school 
life, new approaches try to understand the teacher's work in a manner that reaches beyond academic/scientific knowledge.

According to Nóvoa (1995), Schön (2000) and Ibernon (2010), this approach is distinct from (in opposition to) methods supported by earlier studies that reduced the teaching profession to a range of technical skills and created an identity crisis among teachers resulting from a separation of the professional and the social self. This new conception of the educator's work aims to give voice to the teacher through the analysis and incorporation of their life trajectories and experiences in the classroom.

Some studies on teaching practice and teacher training assert that the school environment bares little resemblance to the official academic guidelines as defined by higher authorities. For example, knowledge-based action as described by Schön (2000), notes that the teacher's professional activities do not involve solving practical problems through the application of theories and scientific techniques. Rather, they rely on the teacher's "know-how," knowledge comprised of rules or plans cultivated in our spirits prior to action.

The author argues that teachers practice "knowledge through action," relying on a thinking process that both precedes and accompanies their actions. External entities impose educational models, standards and guidelines designed to ensure the effectiveness and success of schools. However, day to day practices are unique. It is therefore vital that each school and teacher identify the practices (innovative or not) that will produce positive results for their students.

Given the ever-evolving nature of pedagogical knowledge, teachers often struggle with how to utilize the developments of academic research in their classrooms. They are often left with questions about the validity of their lesson content and whether they are adopting the correct teaching practices. Their doubts are primarily the result of transformations in the "order of knowledge".

Developments in the Social Sciences, or the categories of knowledge that have been developed and elaborated for the benefit of teaching practices to be offered to teachers, have over time, in a certain way, formed part of the educational culture and were put into practice, not in the same way that they were strategically thought out, but in a way that was tactically modified (CERTEAU, 1990). Teachers chose some categories, resisted others (new or old) and modified many more. These "modifications" or individual reconstructions happen so that they can achieve their goals, because the discourses provided for the teachers are not sufficient to 
guide their actions (CHARTIER, 2007). However, when the teacher's knowledge is recognized, the teacher is perceived as an inventive and constructive person, who is able to think about his or her practices and can transform and redirect them from their experiences and new knowledge produced by academia as long as they have an understanding of their own approach to teaching.

There are currently many teachers who, in the management of their classrooms, do not create work routines or refuse to create lesson plans because they believe such practices are based on outdated technical teaching models. There are also teachers who emphasize ideas of citizenship in the classroom but are unable to create an environment where students can acquire reading and writing skills. These teachers often believe that the ways they were taught to read and write are outdated, but they do not know how to do it differently (TARDIF, 1999). In an attempt to understand how continuing education programs aimed at the early grades and how the training of literacy teachers has been conceived, the issues of training in order to improve teaching practice, with respect to literacy, we'll be showing some discussions about changes that aim to influence the teacher in the reading and writing education.

\section{Literacy: a review of the concept}

According to numerous authors including Braslavsky (1988), Chartier (2007), Morais (2005), Mortatti (2006), Rocha and Martins (2014) methods for teaching literacy were first developed in the $17^{\text {th }}$ century when unprecedented social transformations led largely illiterate populations to demand a basic education in reading and writing.

In the late nineteenth-century, literacy practices based on the teaching of coding and decoding skills were developed. These advances were based on the creation of different models of literacy - syllabic / synthetic methods x global/analytical methods, mixed method x natural method - that standardized how individuals learned to read and write. As stated Chartier et al. (1996), every great advance in the history of teaching literacy, has resulted in the placement of different methods in binary opposition to one another.

Throughout most of the 20th century, particularly during the period prior to the 1970's, most believed that acquiring teaching skills for reading and writing was primarily an issue of methods (MORTATTI, 2006; SOARES, 2003). In Brazil, as well as other countries, a fierce competition between diverging literacy methods emerged. This was primarily a clash between the so-called "synthetic methods", which proceeded from the "small parts" (phonemes, syllables) to the "whole", 
and "analytical methods", which adopted the opposite approach: the "whole" for "small parts".

The "synthetic methods" initially evolved to the letter (alphabetic or spelling method) and the phoneme (phonics) or syllable (syllabic or hyphenated method). These methods were combined through a synthesis of larger linguistic units (words, phrases and texts): the letters or phonemes were assembled into syllables which were assembled into words and so on. The "analytical methods" (or global), in opposition to the synthetic ones, came from larger units of language: word ("palavração" method which means "from words to syllables"), phrase (sentencing method) and text (method based on tales and anecdotes). In these methods, the words, phrases or texts were broken down through a process of analysis, in smaller language units (syllables, letters and words): the text was broken down into phrases, which were broken down into words and so on.

According to Braslavsky (1988), traditional methods, whether synthetic or analytical, shared an empiricist-associationist conception of teaching and learning. Since the starting point for teaching reading and writing varied (texts in global methods, phonemes in phonic methods, etc.), it was commonly believed that, in order to teach the Alphabetic Writing System (SEA), the school needed to provide prefabricated (predetermined) information on sound-spelling relationships for the student to memorize. With these methods, alphabetic writing was understood as a code and not as a notational system, as shown by Morais (2005), and its learning would depend on psychomotor or perceptual and mnemonic capacities that, at different times in the 20th century, came to be understood as requirements for literacy.

This approach changed the pedagogical discussion on literacy by shifting the focus away from teaching methods in order to emphasize the learning process. Based on constructivist principles, this approach is not presented as yet another "revolutionary new method." It is, instead, a "conceptual revolution" that requires the abandonment of theories and traditional practices, the "unmethoding" of the literacy learning process. This includes questioning the utility of primers (MORTATTI, 2006, p. 10) that, since the $1980 \mathrm{~s}$, many have criticized as "misteaching" the significance of text and the social function of writing (SOARES, 2003).

According to Soares (2003, p. 11), this "paradigm shift" in the field of literacy, brought some benefits, such as an understanding of the learner's path towards the (re)construction of SEA. But, it also "led to some misconceptions and false inferences," that, in recent decades, has led to a phenomenon the author refers 
to as literacy "un-invention." In other words, the process loses specificity. The author points out that among these false inferences is the conclusion that "the conceptual psychogenetic paradigm would be incompatible with the proposed literacy methods." She explains:

In a way, the fact that the problem of reading and writing learning has been considered as a problem in the context of "traditional" paradigms, especially methodological, contaminated the concept of literacy teaching methods, giving the topic a negative connotation: meaning, that when it comes to literacy "method", one can easily identify "method" as part of the "traditional" method type- synthetic and analytical (phonic, syllabic, global etc.), as if these types were running out of all methodological alternatives for learning to read and write. One might say that previously, there was a method and no theory for the practice of literacy; nowadays, with the changing conception of the process of written-language learning, we begin to see a theory, but there is still no method (SOARES, 2003, p. 11).

We have found that this "unmethoding" of reading and writing teaching led to a false premise that has contributed to the "un-invention" of literacy: a belief that the student would become literate "through intense interaction with the written material circulating through social practices alone, through their immersion in written culture." This gamble on the spontaneous learning of alphabetic writing is the result of misinterpretations of both constructivist conceptions and existing debates surrounding literacy (SOARES, 2003, p. 13), that, in our country, have served as an "enchantment" for specialists who became less invested in research about learning alphabetic writing.

These circumstances, along with test scores that indicate declining levels of literacy among the current student population, have led some scholars, including many in Brazil, to criticize the approach to learning described above. They have expressed particular concern over the absence of direct and specific instructions for learning alphabetic writing. In doing so, they have defended ideas that would represent a return to previous paradigms, dismissing the progress and achievements made in recent decades (SOARES, 2003).

Based on Ferreira's (2007) studies, we can conclude that teachers' classroom practices reflect a conflict between the "new" and the traditional that is complicated by the fact that the "new" is presented as right/successful, while the "traditional" is considered as wrong/failure. In the practices of first language teachers in the 
elementary grades, Albuquerque (2006) asserts that, considering recent innovations and the "charges" raised by them, the reaction of these professionals is not the total and instantaneous suppression of the old/traditional procedures. It is not a complete rejection of previously established and consolidated educational practices in the name of incorporating the "new". Instead, attempts at change, on many levels, primarily involve a merging of the old ways with the new ones.

Situating this discussion in the context of literacy, we realized that the "new", or at least what prevails as "new" in academic discourse today involves the teacher's need to teach alphabetic writing from a reflexive perspective, reconciling such work with literacy, in other words, teaching students to read and write by introducing this student to the social practices of reading and writing (SOARES, 2003).

Many teachers have tried to incorporate changes in their practices. However, as Albuquerque (2006) rightly observes, their attempts often involve the implementation of new procedures, such as working with the various popular genres that circulate in society, while simultaneously emphasizing accomplishment of traditional activities such as the memorization of letters or "syllables on the loose", practices widely criticized in recent decades for not promoting reflective learning.

The reconciliation of "new" and old beliefs about what "to do" in the classroom, is part of a construction/"creation" process central to the teachers" daily life. In the current environment, training programs provide a very important bridge between the academic/official instructions and the teaching practice.

\section{Continued training programs in literacy}

Over the last two decades, in the midst of all these debates regarding literacy, many continued training programs for teachers in various areas of education have been developed (FUNDAÇÃO VICTOR CIVITA, 2011). These programs seek to facilitate the incorporation of recent pedagogical transformations in classroom practices. In terms of language education, specifically the teaching of literacy, government agencies have sought to develop literacy training programs for teachers in partnership with MEC and different universities or private institutions that specialize in this area. Such programs have been developed in several states and cities and have adopted different formats and methodologies for the continued training of early elementary reading teachers.

According to Gatti (2003) and Fundação Victor Civita (2011), the appearance of several courses and continuing education programs has historical basis on 
emerging conditions in the contemporary society, the challenges to curricula and teaching, to the school systems by the increasing of children and young people welcoming, the difficulties announced and faced by administrators and teachers within the school systems in the everyday life, and detected and analyzed through researches. Then, the discourses of updating and, necessity of renovation were created. Thus, continuing teacher training serves to integrate the educational policies of the country through various programs and projects. In an attempt to reverse the poor performance of our students, especially with respect to language learning, a large number of continuing education programs were created for reading and writing teachers.

Between 2000/2001, the continuing Education Program of Literacy Teachers (Profa) developed a proposal for training teachers in many Brazilian cities. This program involved a curriculum rich with videos, books and materials for use in the classroom. Besides Profa, another program was created with support from the World Bank, the Praler. This program included reading education as part of teacher training with the goal of encouraging independent reading and a desire to read among early elementary school students.

In 2015, the Ministry of Education created a continuing education program that includes language education. The Pró-Letramento program started in the north and northeast regions of the country with the goal of preparing groups of training specialists in several cities in the country. These training specialists would be responsible for organizing the studies with early elementary education teachers in order to help develop a culture of teacher training through a continuous and reflective process within secretariats and schools. ${ }^{2}$

In 2013 the Ministry of Education launched the National Program for Literacy at the Right Age (Pnaic) in order to develop reading and writing skills among children up to the age of eight, through the continuing education of teachers.

In addition to the programs launched by the federal government, many other nongovernmental programs were created such as Airton Senna Institute programs (Acelera Brasil/Se liga) and the Alfa e Beto literacy proposal (that promotes a particular method of literacy teacher training). These programs have been offered to state and local school systems throughout Brazil. Many of these, in one way or another, are based on the idea of continuing teacher education. However,

2 Unable to make an exhaustive exposure of all continuing education programs for existing teachers in the area of mother tongue teaching, we have chosen to introduce some of whom have made and/or are still part of the reality of some municipalities in Pernambuco. 
they utilize different teaching and learning concepts and have adopted different training devices.

The Alfa e Beto program, for example, has been adopted in several cities. It aims to teach reading and writing as a decoding and encoding process that it combines with the use of teaching materials based on phonics literacy. The program claims that the literacy process involves the mastery of a limited set of skills, such as: alphabet discovery, discovery of the alphabetic principal, automatic word recognition, reading fluency and the spelling code.

From the current proposals for continuing education aimed at Portuguese learning education, presented by official or non-governmental programs, we can think about many factors that we consider essential to our understanding of and continued reflection on the process of continuing education of teachers: what teaching concepts language and literacy are the proposals based on? How the teacher and the teaching practice are conceived? These are the central questions guiding the development of this work.

\section{Methodology}

In this research, due to the varied nature of the subject and theoretical preferences, we privilege an ethnographic perspective of Qualitative Research, which, according to Denzin and Lincoln (1994), is based on the description and interpretation of human groups and involves intense and multifaceted contact, placing value on actions, the symbolic elements of social relations. André (1997, p. 41) says that in the ethnographic study, particularly of schools, you must focus your lens on the dynamics of interpersonal relationships:

by identifying the power structures and the way schools are organized and understanding the role and status of each subject in this interactional context where actions, relationships, and content is built, denied, rebuilt and modified.

The research presented here was conducted in two municipalities of Pernambuco in the metropolitan region of Recife: Jaboatão dos Guararapes and Camaragibe. We chose these municipalities because they were developing differentiated literacy teachers training programs at the time the survey was conducted (2010-2011). Jaboatão adopted the Alfa e Beto literacy program (2009-2012) and Camaragibe had participated in teacher's formation training courses offered by the Center for Studies in Education and Language (CEEL), 
which belongs to the National Network of Teacher Training of the Ministry of Education (2004-2014).

Our methodological procedures included the observation of five teacher training meetings in Camaragibe and three in Jaboatão dos Guararapes ${ }^{3}$, and an analysis of the material used in this training. The observations were audio recorded and later transcribed.

Before presenting the survey results, we think it is important to provide a profile of the city that highlights its experiences in continuing teacher education.

The municipality of Camaragibe's belongs to the metropolitan area of Recife, and it is the sixth most populous city (Camaragibe population in 2013 was 151,587 according to IBGE). There were 9,636 students enrolled in the school system.

As discussed by Gama (2014), the continued training of literacy teachers in the city of Camaragibe was conducted by the Study Group on Education, Research and Action Methodology - Geempa - from Rio Grande do Sul. It was a program aimed at literacy teachers who were interested and available to participate in training meetings outside their working hours. The program emphasized the study of written language psychogenesis and the evaluation and classification of students' writing. Since 2006, the Department of Education has partnered with the CEEL of the Federal University of Pernambuco, a member of the National Center of the Ministry of Education Teacher Training Network. Several courses have been offered since then, in order to meet the existing demand (for all teachers from $1^{\text {st }}$ to $5^{\text {th }}$ grade of elementary school teaching network).

The municipality of Jaboatão dos Guararapes also belongs to the metropolitan area of Recife. Its estimated population according to the IBGE in 2014 is 675,599 inhabitants, making it the second most populous city in the state of Pernambuco. There were 87,223 students enrolled in Elementary Education.

The Department of Education of Jaboatão dos Guararapes has offered continuing teachers education activities since the late 1990s. It has also participated in the Pró-letramento National Program and in 2009 adopted a private literacy training program for early elementary teachers, Alfa e Beto. In 2013, it joined the Pnaic.

3 The training process in Jaboatão took only three meetings. 


\section{Results and discussions}

\subsection{The continuing teachers training in Camaragibe}

During the year this research was conducted (2010), the continuing training of literacy teachers in Camaragibe took place on a monthly basis, with each meeting lasting four hours. The Curriculum Proposal of the city was created with the participation of teachers and technicians from the city's Department of Education and with the assistance of teachers/CEEL researchers. It was published at the beginning of that year. Also in 2010, the PNLD 2010 textbooks arrived, texts that were selected in 2009 by teachers representing each school. In this context, pursuing the continuing education experiments conducted in partnership with the CEEL, the Department of Education requested a more focused training to build literacy practices from the perspective of "reading through writing", focusing on reading writing, using the PNLD textbooks and other materials, and also based on the proposed curriculum of the school system.

As previously mentioned, we observed five training meetings in the morning shift from August to December 2010 in order to understand how these meetings were characterized and contributed to the construction of literacy practices. Table 1 shows the training strategies and the themes discussed throughout the training.

We discuss bellow each one of the training strategies developed in the observed meetings.

- $\quad$ Pleasure reading

Table 1. Training strategies performed in the continuing education of Camaragibe.

\begin{tabular}{lccccc}
\hline Activities & $\begin{array}{c}\text { Meeting } \\
\text { I }\end{array}$ & $\begin{array}{c}\text { Meeting } \\
\text { II }\end{array}$ & $\begin{array}{c}\text { Meeting } \\
\text { III }\end{array}$ & $\begin{array}{c}\text { Meeting } \\
\text { IV }\end{array}$ & $\begin{array}{c}\text { Meeting } \\
\text { V }\end{array}$ \\
\hline $\begin{array}{l}\text { Pleasure reading } \\
\begin{array}{l}\text { Recover professional } \\
\text { occurrences/experiences } \\
\text { socialization }\end{array}\end{array}$ & $\mathrm{X}$ & $\mathrm{X}$ & $\mathrm{X}$ & $\mathrm{X}$ & $\mathrm{X}$ \\
$\begin{array}{l}\text { Collective discussion about the } \\
\text { object of reflection }\end{array}$ & $\mathrm{X}$ & $\mathrm{X}$ & $\mathrm{X}$ & & $\mathrm{X}$ \\
$\begin{array}{l}\text { Groups work } \\
\text { Groups work socialization }\end{array}$ & $\mathrm{X}$ & $\mathrm{X}$ & $\mathrm{X}$ & $\mathrm{X}$ & - \\
\hline
\end{tabular}

Source: Observation of teacher training meetings (2011/2012). 
Each training meeting began with welcoming the teachers, followed by writing the meeting's agenda on the board. The first strategy session was the "pleasure reading" session conducted by the formation trainer. This activity consisted of the trainer reading a book or a text (literary or not) that would provide a pleasant experience. Two sessions focused primarily children's literature. The other three days the trainer read some chronicles and a joke that linked famous characters to chocolates. At this point, the teacher realized the operation of reading strategies before, during and after reading the text, depending on the text that was being read. By the end of the activity, some teachers commented on these questions stating that they used the same process in their practices. The training emphasized the importance of these strategies to keep the class interested and to help the students understand the text. We hoped that through this experiencing activity, done in each and every meeting, the teachers would realize the importance of daily achievement in their teaching practices of reading literary texts for their students.

\section{- Experiences socialization}

Also, during the five meetings we observed, after the reading pleasure segment, that there was a time dedicated to sharing experiences before the next segment of the meeting. Teachers reported situations experienced with their classes, such as the progression of teaching sequences and the difficulty in assessing students. The sharing session was also conducted during the last meeting of the year $\left(5^{\text {th }}\right.$ observation) and involved the discussion of experience reports produced by class teachers.

- Collective discussion about training themes

The questions posed in the training meetings prioritized adopting methods of the SEA while simultaneously working with different genres. For doing so, one of the strategies developed was the collective discussion with the former mediation. In the second training meeting, for example, after the pleasure reading, the trainer proposed reading and discussion of a didactic sequence developed by a teacher of the public system which involves the reading of a poem about jokes. She explored with the group of teachers, how the axis of the Portuguese language teaching (reading, alphabetic writing appropriation, text production and orality) were contemplated in her work and how they could enrich it. In the other three days, the former mediated a discussion about the following themes: learning mapping related to the appropriation of alphabetic writing, spelling, changes in the textbooks of literacy. 
- Groups work and activities socialization

Besides the already discussed strategies, in four of the five training meetings there was a proposal of working in small groups which mainly involved an examination of the city's proposed curriculum and the analysis of textbooks based on this proposal. We will provide an overview of how these activities were carried out in each one of the meetings.

- On the first day of observation, after having read and discussed a report of experience involving the development of a didactic sequence, the teachers gathered in small groups to analyze sequences from textbook activities. They were asked to identify, in the sequence provided, the principles of teaching Portuguese contemplated and the components of the alphabetic writing system presented in each activity. It would be possible, in this case, to rely on the public system proposal for Portuguese learning that was organized based on educational guidelines and, in the case of the SEA appropriation, the principles would be presented.

- On the second day, after a discussion of the student mapping in relation to SEA appropriation, with emphasis on the alpha level, the teacher started a discussion about spelling based on examples of alphabetic scripts with different spelling problems. Then the teachers in groups would analyze textbooks activities approved by PNLD aimed at teaching the SEA and spelling. They should identify the objectives of the activities and could rely on the network's proposal for Portuguese learning.

- On the third day, the trainer held an oral presentation on changes in books for teaching literacy, encouraging teachers to talk about their own experiences, either as students or as teachers. Then they collectively analyzed activities from new and old books. In groups, they analyzed a series of activities from one of the books used by the network.

- Finally, on the fourth day of observation, they also worked in groups to analyze a series of activities involving the four core teaching principles of the Portuguese language, presented in textbooks. But to do so, they were asked to rely on the network's program. 
During the analysis of the activities from textbooks used by teachers, the teacher in charge of the training session asked the participants to identify the objectives of the lessons and the principles related to each activity. She also asked questions about the possibilities and limits of using this material in the classroom, taking into consideration the profile of the classes. She encouraged teachers to think about other activities they could add and how they might modify the activity to meet the needs of particular students.

The training teachers emphasized that the educational strategies presented and practiced during the sessions were flexible, created for the benefit and support of reflective and autonomous teaching practices. The program assumes that, during the educational training, individual and collective contributions by participants will facilitate their professional development. This approach recognizes the elements of personal life and social demands that influence any professional field. However, the guidelines provided do not include specific rules to be followed. Work with different literary genres was demonstrated through shared experiences with textbooks, group activities, pleasure reading and teachers training socialization and evaluations of the teacher and the training specialist that took place at the end of each meeting. This showed the program's respect and understanding of teaching as a profession built upon the professional's ability to make decisions and justify them. And it underscored a belief that education is inherent to reflective practices and the decision-making process.

Thus, we find that the continuing teachers training in the city of Camaragibe took into account the teacher's unique practices, the characteristics of his/her classroom, and his/her specific experiences. In doing so, the program favors teacher's autonomy by giving time and voice to the professional.

\subsection{Continuing teachers training in Jaboatão dos Guararapes}

The Alfa e Beto program's approach to teacher training includes some peculiar elements- most notably, the classroom materials it utilizes and the assistance teachers receive from coordinators. It is assumed that teachers will alter their everyday practices in order to allow for the use of these materials.

The training process at Jaboatão dos Guararapes always happened in the same format, as shown below:

Based on the data presented in the table above, we see in the continuing teachers training program at Jaboatão dos Guararapes, three formative strategies: 
Table 2. Training strategies performed in the continuing education at Jaboatão dos Guararapes.

\begin{tabular}{lccc}
\hline Activities & Meeting I & Meeting II & Meeting III \\
\hline Reception & $\mathrm{X}$ & $\mathrm{X}$ & $\mathrm{X}$ \\
Orientations about the Alfa e Beto Program & $\mathrm{X}$ & $\mathrm{X}$ & - \\
Groups work & $\mathrm{X}$ & $\mathrm{X}$ & $\mathrm{X}$ \\
Groups work socialization & $\mathrm{X}$ & $\mathrm{X}$ & $\mathrm{X}$ \\
\hline
\end{tabular}

Source: Observation of teacher training meetings in Jaboatão dos Guararapes (2011).

reception, orientations about the Alfa e Beto Program, groups work and groups work socialization. We present as follow, how these strategies were developed.

\section{- Reception}

In the beginning, there was always a reception with activities that aimed to get the participants more acquainted with one another. In the first two meetings, the teachers watched a video and then they made a discussion about it (the first one was the Brazilian short film "Vida Maria" by Márcio Ramos, and the second one was about Easter). The third meeting started with a song.

\section{- General guidelines about the Alfa e Beto Program}

In the first two meetings, after the reception moment, the trainer gave the teachers some guidelines about the program. On the first day, there was a presentation of all the materials of the Program. On the second day, there was a presentation and the delivery of the calendar of activities and the lesson plans related to the first two lessons that should be developed within five school days, each (the other lessons should be developed within eight school days). The plans were made by the coordinator of the program and presented to the teachers who should apply them as they had been thought.

- Groups work and activities socialization

The group work done during the three days of observation involved reading the materials to be used by the students, as indicated in the instruction manual for teachers, followed by discussion of questions that came up during the reading. We also noted that the activity focused on the use of the didactic materials - the 
textbooks Aprender a Ler e Manual de Consciência Fonêmica - and emphasized how they should be used with students to ensure that teachers would use the materials in the way they were prescribed.

In the first meeting, the teachers explored the material in groups. In the other two ones, they studied the lessons plans of other actions of the program to appropriate them. In the group work socialization, the teachers took questions about the activities proposed in the lesson plans and talked about how the program is used in the classroom. It was noticed that they did not accept the program willingly.

Differently from the training experienced in Camaragibe, the teaching training proposed by Alfa e Beto Literacy Program offered no review of previous training sessions. This created the impression that there was no continuity between the sessions and no attention was given to the relationship between the material presented and previous lessons. The teachers who participated were never asked to speak about their own experiences in the classroom. During the training, they were not encouraged to reflect on their teaching practices. They were asked to reflect on the possibilities of using the materials offered by the Alfa e Beto Program taking into consideration the differing conditions of local schools. There was no opportunity to ask about activities that could be added or how teachers could alter the offered lesson plans to better meet the needs of their students. The emphasis was given on reading the book activities. In the cases in which the participant expressed doubts about what was proposed in the textbooks, the teacher was asked to explain them in order to ensure if they had fully understood the material.

In the training sessions, teachers were seen as program implementers. The coordinators provided little time for reflection or debate about whether the proposed activities would be effective for their students. There was no discussion on how the lesson plans might be adjusted to meet the needs of students with different levels of knowledge and writing skills. They also failed to address how teachers might integrate the program's materials with what they were currently doing in the classroom. The program seems to envision the role of the teacher as what Monteiro (2001) describes as a simple "doer" of previously elaborated tasks (with steps to be followed) in a collection of progressive exercises, tasks, steps and exercises defined by the guidebooks they received.

In the meetings, teachers' prior knowledge and experience was ignored because the training was designed to focus solely on the official methods and goals of the program. The teachers completed activities in a manner that was completely disconnected from the social practice of reading and writing. This understanding 
of teaching and learning is reflected in the way the training was planned and carried out.

\section{Some considerations}

In our analysis of the training and practices of local teachers, it was concluded that, in both cities, there is a dialogue between training practice and teaching. Differences between the municipalities primarily involve the way training and teaching of the mother tongue has been conceptualized.

The analysis of the continued training from Camaragibe revealed an education training that prioritizes working with activities taken from the SEA, contemplating the core principles of the Portuguese language, through the reading through writing approach to literacy, with the analysis of the textbook teachers currently use and the study of the municipality's curriculum proposal. During all of the training sessions, teachers analyzed and planned for common classroom situations. The training dynamic in this municipality was organized around a routine involving pleasure reading, past experience recovery, didactic sequence analysis (activities from the textbook/appropriation of SEA, didactic sequence from an anonymous teacher), group analysis, socialization of experiences and the evaluation of both the teacher and the training facilitator. There were differences in the training devices used.

The analysis of continuing teacher training from Jaboatão dos Guararapes revealed a formation that prioritized work with literacy activities based on encoding and memorization. The teacher in all formations received the guidelines to be applied, later followed in the classroom, but that would not value their knowledge and skills through experience. Thus, the conception of training and teaching of mother tongue is in "transmissive" and receptive formats.

We noticed that the Camaragibe training sessions showed a true interest in providing continuing education that recognizes teachers' strengths and their ability to think, plan, modify, and develop innovative teaching practices whenever necessary. Such actions are reflected in the everyday practices of the teachers we observed during our research. In contrast, the city of Jaboatão dos Guararapes acquired a private training program, ready to follow, step by step, disregarding the teaching knowledge and reflection on existing literacy teaching practices, imposing a model of an education that was directive and repetitive for both teachers and students. 


\section{Programas de formação continuada de professores alfabetizadores: concepções e práticas}

\section{Resumo}

Este artigo analisa as propostas de formação continuada de professores em alfabetização em dois municípios da região metropolitana do Recife, no sentido de entender as concepções de língua e formação que fundamentam tais práticas. Os resultados apontam grandes diferenças entre as experiências de formação nos dois municípios. Em Camaragibe, a proposta de formação baseava-se na reflexão docente e respeitava a autonomia do professor como construtor de suas práticas de ensino, além de favorecer a compreensão do ensino da língua como prática social. Em Jaboatão, a formação correspondia ao treinamento para o uso de materiais didáticos elaborados para serem seguidos pelo professor, considerado como executor de tarefas.

Palavras-chave: Alfabetização. Programas de formação continuada. Política educacional.

\section{Programas de formación continua de maestros de lectoescritura: conceptos y prácticas}

\section{Resumen}

Este articulo analiza las propuestas de formación continua de maestros de lectoescritura en dos municipios de la región metropolitana de Recife, con el fin de entender los conceptos del lenguaje y de la formación que apoyan este tipo de prácticas. Los resultados muestran que hay grandes diferencias entre las prácticas de formación en ambas ciudades. En Camaragibe, la propuesta de formación se basa en la reflexión de la enseñanza y en el respeto a la autonomía del maestro, diseñador de sus prácticas de enseñanza, y en promover la comprensión de la lengua como una práctica social. En Jaboatão, la formación corresponde al uso de materiales diseñados para ser seguidos por el maestro, considerado como ejecutor de tareas.

Palabras clave: Enseñanza de la lectura y la escritura. Formación continua. Política educativa. 


\section{References}

ALBUQUERQUE, E. B. C. Mudanças didáticas e pedagógicas no ensino de língua portuguesa: apropriações de professores. Belo Horizonte: Autêntica, 2006. (Coleção Ensino da língua portuguesa).

ANDRÉ, M. Políticas e programas de apoio aos professores iniciantes no Brasil. Cadernos de Pesquisa, v. 42, n. 145, p. 112-29, jan./abr. 2012. http://doi.org/10.1590/S0100-15742012000100008

ANDRÉ, M. E. D. A. Tendências atuais da pesquisa na escola. Cadernos Cedes, v. 18, n. 43, p. 46-57, dez 1997. http://doi.org/10.1590/S0101-32621997000200005

BRASLAVSKY, B. O método: panacéia, negação ou pedagogia? Cadernos de Pesquisa, n. 66, p. 41-8, ago.1988.

BRITO-FERREIRA, A. T.; CHARTIER, A.-M. Brésil - France au quotidien de l'école. Diversité, n. 150, p. 179-89, 2007.

CERTEAU, M. D. L'invention du quotidien. 2. ed. Paris, Gallimard, 1990. V. 1: L'art du faire.

CHARTIER, A.-M. Práticas de leitura e escrita: história e atualidade. Belo Horizonte. Autêntica, 2007.

CHARTIER, A.-M.; HÉBRARD, J.; CLESSE, C. Ler e escrever: entrando no mundo da escrita. Porto Alegre: Artmed, 1996.

DENZIN, N.; LINCOLN, Y. (Eds.). Handbook of qualitative research. Londres: Sage, 1994.

FERREIRA, A. T. B. As práticas cotidianas dos profissionais da escola.. In: FARIAS, M. S. B.; WEBER, S. (Orgs.). Pesquisas qualitativas nas ciências sociais e na educação: propostas de análise do discurso. João Pessoa: Ed. Universitária- UFPB, 2008, p. 241-60.

FUNDAÇÃO VICTOR CIVITA. Formação continuada de professores: uma análise das modalidades e das práticas em estados e municípios brasileiros: relatório final. São Paulo, 2011. (Estudos \& pesquisas educacionais).

GAMA, Y. M. S. Construções das práticas de alfabetização: elementos da formação continuada mobilizados no cotidiano da sala de aula. 2014. 274 p. Tese (Doutorado em Educação) - Universidade Federal de Pernambuco, Recife, 2014. 
GATTI, B. Formação continuada de professores: a questão psicossocial. Cadernos de Pesquisa, n. 119, p. 191-204, 2003. http://doi.org/10.1590/S0100-15742003000200010

IBERNON, F. Formação continuada de professores. Porto Alegre: Artmed, 2010.

LÉLIS, I. A. A formação da professora primária: da denúncia ao anúncio. São Paulo: Cortez, 1989. (Coleção Educação contemporânea).

MONTEIRO, A. M. F. C. Professores: entre saberes e práticas. Educação e Sociedade, v. 22, n. 74, p. 121-42, 2001. http://doi.org/10.1590/S0101-73302001000100008

MORAIS, A. G. Se a escrita alfabética é um sistema notacional (e não um código), que implicações isso tem para a alfabetização? In: MORAIS, A.; ALBUQUERQUE, E.; LEAL, T. Alfabetização: apropriação do sistema de escrita alfabética. Belo Horizonte: Autêntica, 2005. p. 29-45.

MORTATTI, M. R. L. Os sentidos da alfabetização. São Paulo: Ed. Unesp, 2006.

NÓVOA, A. A profissão professor. 2. ed. Porto: Porto Editora, 1995.

ROCHA, G.; MARTINS, R. F. A apropriação de habilidades de leitura e escrita na alfabetização: estudo exploratório de dados de uma avaliação externa Ensaio: Avaliação e Políticas Públicas em Educação, v. 22, n. 85, p. 977-1000, out./dez. 2014. http://doi.org/10.1590/S0104-40362014000400006

SCHÖN, D. A. Educando o profissional reflexivo: um novo design para o ensino e a aprendizagem. Porto Alegre: Artes Médicas, 2000.

SOARES, M. Alfabetização e letramento. São Paulo: Contexto, 2003.

TARDIF, M. Saberes profissionais dos professores e conhecimentos universitários: elementos para uma epistemologia da prática profissional dos professores e suas consequências em relação à formação para o magistério. Rio de Janeiro: PUC-Rio, 1999. (mimeo). 


\section{Informações dos autores}

Andrea Tereza Brito Ferreira: Professora associada do Departamento de Métodos e Técnicas de Ensino e vice-coordenadora do Programa de Pós-graduação em Educação da Universidade Federal de Pernambuco - UFPE. Membro do Centro de Estudos em Alfabetização e Linguagem -CEEL e do GT 10 da ANPEd. Contato: andreatbrito@gmail.com

Eliana Borges Correia de Albuquerque: Professora associada do Departamento de Psicologia e da Pós-graduação em Educação da Universidade Federal de Pernambuco - UFPE. Membro do Centro de Estudos em Alfabetização e Linguagem - CEEL e do GT 10 da ANPEd. Contato: elianaba@terra.com.br

Erica Windler: Professora assistente do Departamento de História da Michigan State University, EUA. Suas pesquisas são sobre História da Infância, Família e Gênero no Brasil. Contato: windler1@me.com 